\title{
Coniacian to Maastrichtian stage boundaries in the standard section for the Upper Cretaceous white chalk of NW Germany (Lägerdorf-Kronsmoor- Hemmoor): Definitions and proposals
}

\author{
MAX-GOTTHARD SCHULZ, GUNDOLF ERNST, HARTMUT ERNST and FRIEDRICH SCHMID
}

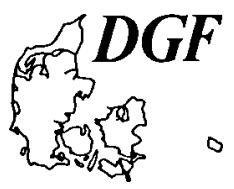
Schulz, M.-G., Ernst, G., Ernst, H. and Schmid, F.: Coniacian to Maastrichtian stage boundaries in the
standard section for the Upper Cretaceous white chalk of NW Germany (Lägerdorf - Kronsmoor -
Hemmoor): definitions and proposals. Bull. geol. Soc. Denmark, vol. 33, pp. 203-215, Copenhagen,
September, 11th, 1984. https://doi.org/10.37570/bgsd-1984-33-19

\begin{abstract}
Four large quarries in northern Germany provide a continuous section from the Middle Coniacian to Upper Maastrichtian, consisting almost throughout of a white chalk facies. The combined section has a thickness of $570 \mathrm{~m}$. It has been sub-divided biostratigraphically into 33 zones. The vertical ranges of the species of the stratigraphically relevant groups have been determined on the basis of about 30 years of systematic collecting of fossils bed by bed. Belemnites, inoceramids, echinoids, crinoids and brachiopods occur throughout the section, ammonites only in the Campanian and Maastrichtian.

The following proposals are put forward for the definition of the stage boundaries:

Campanian/Maastrichtian: appearance of Belemnella lanceolata, nearly coincident with the first occurrence of Hoploscaphites constrictus;

Santonian/Campanian: level of phylogenetic development of Gonioteuthis granulataquadrata from $\boldsymbol{G}$. granulata, coincident with the extinction of Marsupites testudinarius;

Coniacian/Santonian: appearance of Inoceramus (Cladoceramus) undulatoplicatus nearly coincident with the appearance of the Inoceramus pachti/cardissoides group.

M.-G. Schulz, Geologisch-Paläontologisches Institut der Universität, Olshausenstr. 40/60, D-2300 Kiel, Germany; G. Ernst, Institut für Paläontologie der Freien Universität, Schwendenerstr. 8, D-1000 Berlin 33, Germany; H. Ernst, Geologisch-Paläontologisches Institut der Universität, Bundesstr. 55, D-2000 Hamburg 13, Germany; F. Schmid, Niedersächsisches Landesamt für Bodenforschung, Stilleweg 2, D-3000 Hannover 51, Germany. March 8th, 1984.
\end{abstract}

\section{Introduction}

The Upper Cretaceous in northern Germany is exposed in three large quarries at Lägerdorf and Kronsmoor in southwestern Holstein about 50 km northwest of Hamburg and in the Hemmoor quarry, which has been flooded since 1977 , located south of the Elbe River about $35 \mathrm{~km}$ southwest of Lägerdorf. All three localities are on the same elongated salt structure "Krempe-Hemmoor-Bevern". The Upper Cretaceous at Lägerdorf is exposed in two quarries, named "Schinkel" (Middle Coniacian to Lower Campanian; see G. Ernst 1963a, 1966, G. Ernst \& Schulz 1974) and “Alsen" (Lower Campanian to Upper Campanian; see G. Ernst 1963a, Schulz
1978). An exploration borehole in the Schinkel quarry reached the Lower Coniacian (Inoceramus deformis zone). A complete Campanian/ Maastrichtian boundary section is exposed at Kronsmoor in the Saturn quarry about $2 \mathrm{~km}$ north of Lägerdorf (Schulz 1978, 1979). At Hemmoor, the section continues from the middle part of the Lower Maastrichtian (= the top horizon of Kronsmoor) to the Upper Upper Maastrichtian (Schmid 1982, Schulz 1979, Schulz \& Schmid 1983b). The sections of these four quarries can be combined lithostratigraphically and biostratigraphically to provide a nearly complete 570m-thick sequence from the Lower Coniacian to the Upper Upper Maastrichtian, which consists almost throughout of white chalk. 
Thickness of stages in the White Chalk reference section of Lägerdorf-Kronsmoor-Hemmoor

$\begin{array}{lrl}\text { Stage/Substage } & \text { thickness } & \text { quarry } \\ \text { Upper Maastrichtian } & >85 \mathrm{~m} & \text { Hemmoor } \\ \text { Lower Maastrichtian } & 86 \mathrm{~m} & \text { Kronsmoor, Hemmoor } \\ \text { Upper Campanian } & 154 \mathrm{~m} & \text { Alsen, Kronsmoor } \\ \text { Lower Campanian } & 116 \mathrm{~m} & \text { Schinkel, Alsen } \\ \text { Santonian } & 71 \mathrm{~m} & \text { Schinkel } \\ \text { Coniacian } & >57 \mathrm{~m} & \text { Schinkel + borehole }\end{array}$

A detailed description of the combined section with the vertical ranges of the relevant guide fossils is to be published later (Schulz, H. Ernst, Schmid, \& G. Ernst, in prep.).

\section{Palaeogeographical situation}

The Lägerdorf-Kronsmoor-Hemmoor area lies within the area of the transition from the North Sea basin to the Baltic straits, in the northern part of the Pompeckj block and about midway between the land areas of the Baltic Shield and the Mid-European continent. This palaeogeographical location makes the Lägerdorf-Kronsmoor-Hemmoor section a very important link between the northwest European (e.g. England, Limburg) and the east European (Poland, Russia) Upper Cretaceous.

\section{Lithology}

As expected from its palaeogeographical situation far from land areas, probably on a low submarine swell (salt dome), the Upper Cretaceous of Lägerdorf-Kronsmoor-Hemmoor consists almost entirely of very pure, pelagic white chalk with hardly any terrigenous influence. The chalk is extremely fine grained. Only $5-15 \%$ of the components are coarser than $63 \mu \mathrm{m}$. The fraction $<63 \mu \mathrm{m}$ consists mainly of coccoliths. Calcispheres and small planktonic foraminifers are also major components of this fraction.

At the Santonian/Campanian boundary at Lägerdorf, a coarse-grained, ca. $9 \mathrm{~m}$ thick chalk horizon ("Grobkreide"), consisting to a large part (up to $40 \%$ ) of inoceramid prisms, is intercalated in the white chalk (Voigt 1954, G. Ernst 1963a, H. Ernst 1978). The uppermost Maastrichtian chalk at Hemmoor is also somewhat different from the typical white chalk facies. It is greyish to yellowish and rather coarse grained.

The white chalk is only moderately compacted and not cemented. The $\mathrm{CaCO}_{3}$ content of the chalk is about $95 \%$ in the Coniacian and Santonian. It increases to ca. $98 \%$ in the middle part of th Campanian, then decreases to $93-94 \%$ in the upper part of the Upper Campanian and the lowermost Maastrichtian and then increases again to more than $96 \%$, reaching a second maximum of ca. $98 \%$ in the lower and middle parts of the Upper Maastrichtian. In both intervals in which the $\mathrm{CaCO}_{3}$ content reaches a maximum, the content of flint also reaches a maximum, but the Lower Upper Campanian, which also has $\mathrm{CaCO}_{3}$ contents of $97-98 \%$, is alsmost free of flint (see below).

The Coniacian to Lower Maastrichtian chalk of Lägerdorf and Kronsmoor was deposited at water depths of 50-200 m (H. Ernst 1978). The uppermost Maastrichtian chalk of Hemmoor and Basbeck (1 km south of Hemmoor) was probably deposited in shallower water within the euphotic zone (Wetzel 1942, Schulz \& Schmid 1983b). The "Grobkreide" interval at the Santonian/Campanian boundary is also interpreted as a sediment deposited at a shallow depth of about $50 \mathrm{~m}(\mathrm{H}$. Ernst 1978), indicating rising of the salt dome during the "Wernigeröder Phase" (Voigt 1954).

The sedimentation rate of the compacted chalk was about $2.5 \mathrm{~cm} / 1000$ years for the Santonian and Campanian of Lägerdorf and Kronsmoor. It increased to ca. $3.5 \mathrm{~cm} / 1000$ years in the Maastrichtian at Kronsmoor and Hemmoor. Considering the compaction and numerous horizons that indicate reduced chalk sedimentation, the real accumulation rates must have been much 
higher. Bromley $(1979$, p. 28$)$ estimate the rate of deposition of the Maastrichtian of Denmark, which is 3 to 4 times as thick as at Kronsmoor and Hemmoor, to be $20-25 \mathrm{~cm} / 1000$ years.

The chalk is extremely bioturbated throughout the section. The bedding is only visible in a few bedding planes, several thin marl beds intercalated in the chalk and in several horizons of grey, marly chalk (88-90\% $\mathrm{CaCO}_{3}$ ) and blue, pyrite impregnated chalk. In addition, the numerous beds of nodular flint, which are always parallel to the primary bedding planes, can be used for measuring the section and for bed-by-bed collection of samples.

Marl beds are quite comnon in the Coniacian. In the Santonian, only a few thin marl beds occur. Three distinctive marl beds are found in the Lower Campanian and three marl beds occur in the lower part of the Upper Campanian, one of them marking the base of this substage. Another marl bed in the Maastrichtian is very important as a marker horizon for the boundary between the Lower and Upper Maastrichtian (see below).

All transitions occur: from bedding planes to thin marl seams to $1-8 \mathrm{~cm}$-thick marl beds. Valeton $(1959,1960)$ demonstrated the volcanic origin of the clay minerals in some of the marl beds and interpreted them as tuffite beds. But Scholz (1973) showed that the composition of the clay minerals, finely distributed in the normal white chalk, does not differ qualitatively or quantitatively from that in the marl beds. Studies on foraminifer assemblages indicate that the concentration of the clay particles in the marl beds is due to selective dissolution of $\mathrm{CaCO}_{3}$ caused by stagnant water, rather than to a single volcanic event (H. Ernst 1978, 1982).

The pyrite impregnated beds called burrow horizons ("Grabganglagen") are another indicator of reduced chalk sedimentation rates (G. Ernst \& Schulz 1974, H. Ernst 1978). They are speckled blue to black by pyrite impregnation of burrow fills and remains of siliceous sponges. All transitions occur from thin $(10 \mathrm{~cm})$ intensively discoloured beds, which, apart from the hardening, resemble the "sponge beds" of the English Upper Chalk, to thick (several metres), faintly discoloured beds, whose colour very quickly disappears when they are exposed to the air.

Apart from the above-mentioned indicators of reduced chalk sedimentation (marl beds and pyrite impregnated beds), which are more common in the lower part of the section than in the upper part, the section of Lägerdorf-KronsmoorHemmoor seems to be nearly continuous. Hardgrounds in particular are missing and no biostratigraphic indications of major gaps have been found.

Flint is quite common from the Coniacian to the Lower Campanian and from the Upper Lower Maastrichtian to the top of the section, but there is almost none in the Upper Campanian and lower part of the Lower Maastrichtian. Flint usually occurs in nodular beds, which are always parallel to the primary bedding planes. The flint nodules in the Coniacian are white to light grey and have a high porosity similar to that of the surrounding chalk (Scholz 1973). Flints in the Santonian are mainly grey, whereas those in the Campanian and Maastrichtian are black and dense.

The first minor maximum of flint content is found in the middle part of the Lower Campanian, where distinct nodular beds occur with an average distance between beds of about $1 \mathrm{~m}$, perhaps indicating rhythmic changes in the conditions that governed the formation of the flint beds. After a very long interval spanning the whole of the Upper Campanian and the lower part of the Lower Maastrichtian, in which only a very few flint beds occur, flints begin to appear again in the upper part of the Lower Maastrichtian. This reappearance occurs at exactly the same stratigraphic level $35 \mathrm{~km}$ apart at Kronsmoor and Hemmoor: immediately above the base of the upper Belemnella sumensis zone (Schulz 1978, 1979). The greatest flint maximum in the section occurs in a $17 \mathrm{~m}$ thick interval in the Upper Maastrichtian (argentea/junior zone), where twelve continuous, almost massive flint beds with thicknesses of up to $80 \mathrm{~cm}$ occur. That this flint maximum can be correlated with a similar flint maximum in the Upper Cretaceous of Limburg (craie grossière) is demonstrated by the appearance of the coccolith Nephrolithus frequens just above the maximum in both areas (Schulz \& Schmid 1983b).

A very detailed lithostratigraphic scheme has been established by numbering all recognizable beds, such as flint beds, marl beds, and pyrite impregnated beds, and then measuring the distances between them. More than 300 marker 
horizons have been numbered and characterized. Established by biostratigraphic evidence, they allow an exact correlation of the sections of the four quarries.

It is not intended to establish a formal lithostratigraphy for the Lägerdorf-Kronsmoor-Hemmoor section. The only effect would be the introduction of a lot of unnecessary new names. The very detailed lithostratigraphic scheme with numbered guide horizons makes precise bed-by-bed collecting of fossil specimens and micro- samples possible and the detailed faunal zonation enables correlation with the chronostratigraphic units.

\section{Biostratigraphy (figs. 1-3)}

Macrofossils have been systematically collected, bed by bed, for the past thirty years in the quarries at Lägerdorf, Kronsmoor, and Hemmoor on the basis of a detailed lithostratigraphic scheme. A large collection of fossils is now available, even from the lower part of the section (Coniacian to Middle Santonian), where macrofossils are relatively rare. The several thousand specimens of belemnites, inoceramids, and echinoids in particular allow a detailed biostratigraphic subdivision of the combined section into 33 faunal zones. These zones are mainly range or concurrent range zones. Some are interval or assemblage zones. The Coniacian is divided into four zones, the Santonian into six, the Lower Campanian into seven, the Upper Campanian into six, the Lower Maastrichtian into six, and the Upper Maastrichtian into four.

Preferably, members of evolutionary lineages, investigated in detail, were used for zonal division, e.g. the genera Gonioteuthis (G. Ernst 1963a, 1964; G. Ernst \& Schulz 1974), Belemnella (Schulz 1979), and Offaster/Galeola (G. Ernst 1971). Experience has shown that such evolutionary lineages, defined by simple, progressively evolving characteristics, are very important for a reliable correlation with other regions, especially if the sediments are of different facies. The sudden appearance of a species whose ancestor is unknown (most of the classical guide fossils) is, of course, much more convenient for the definition of zonal boundaries, but the vertical ranges may be different in other regions.
The zonal subdivision is based mainly on inoceramids (Cremnoceramus, Volviceramus, and Sphenoceramus) in the lower part of the section (Coniacian to Middle Santonian). In the Middle and Upper Santonian and in the Lower Campanian, members of the evolutionary lineages of Gonioteuthis and Offaster/Galeola are the most important guide fossils. In addition, the crinoids Uintacrinus socialis and Marsupites testudinarius are very useful for the subdivision of the Upper Santonian. The Upper Campanian is subdivided using species of the genus Belemnitella, irregular echinoids, and the ammonites Pachydiscus stobaei and Bostrychoceras polyplocum.

The Lower Maastrichtian can be subdivided into six zones using members of the two parallel evolutionary lineages of the genus Belemnella. Since the investigation of the Belemnitella junior group (Schulz \& Schmid in prep.) is not yet completed, the Upper Maastrichtian has been provisionally subdivided using pteriomorphic pelecypods (Tenuipteria, Spyridoceramus, and Oxyto$\mathrm{ma}$ ) and the regular echinoid Tylocidaris baltica.

The faunal zone succession worked out for the Lägerdorf-Kronsmoor-Hemmoor section can be used in nearly all sections in northwest Germany, e.g. Lüneburg, Misburg, and Münster basin, which are in more marly facies. Even extremely different facies like the Santonian "Trümmererz" in the Salzgitter area can be correlated rather precisely with the Lägerdorf-Kronsmoor-Hemmoor section (G. Ernst 1968).

Owing to the geographical location, the Lägerdorf-Kronsmoor-Hemmoor section is an important link between the western and eastern European Upper Cretaceous. Faunal elements of both provinces occur here. A rather precise correlation is possible, especially with the English Upper Chalk (e.g. G. Ernst 1963a, 1966; G. Ernst \& Schulz 1974; Bailey, Gale, Mortimore, Swiecicki, \& Wood 1983a) and the Maastrichtian of Limburg (Schulz \& Schmid 1983b). Parts of the Lägerdorf-Kronsmoor-Hemmoor section (e.g. the Lower Maastrichtian Belemnella sumensis zone) can even be very precisely correlated with sections in the northern Tethys region (Helvetian and Ultrahelvetian), where belemnites occur abundantly in some horizons (Schmid \& Schulz 1979; Schulz \& Schmid 1983a).

In addition to the macrofossil groups mentioned above, several groups of macrofauna (e.g. 


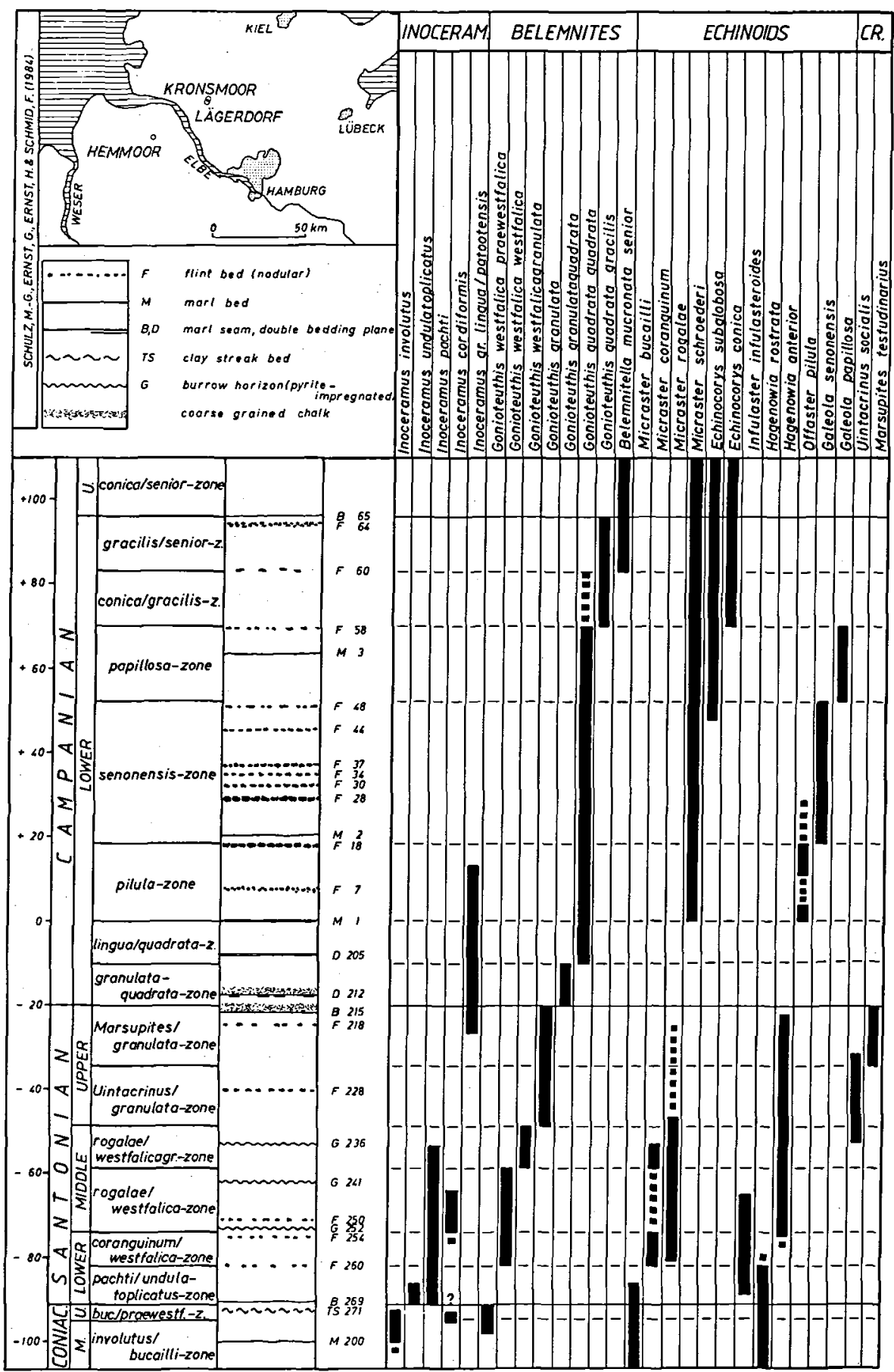

Fig. 1. Stratigraphic ranges of the most important guide fossils in the Coniacian, Santonian, and Lower Campanian of Lägerdorf. 


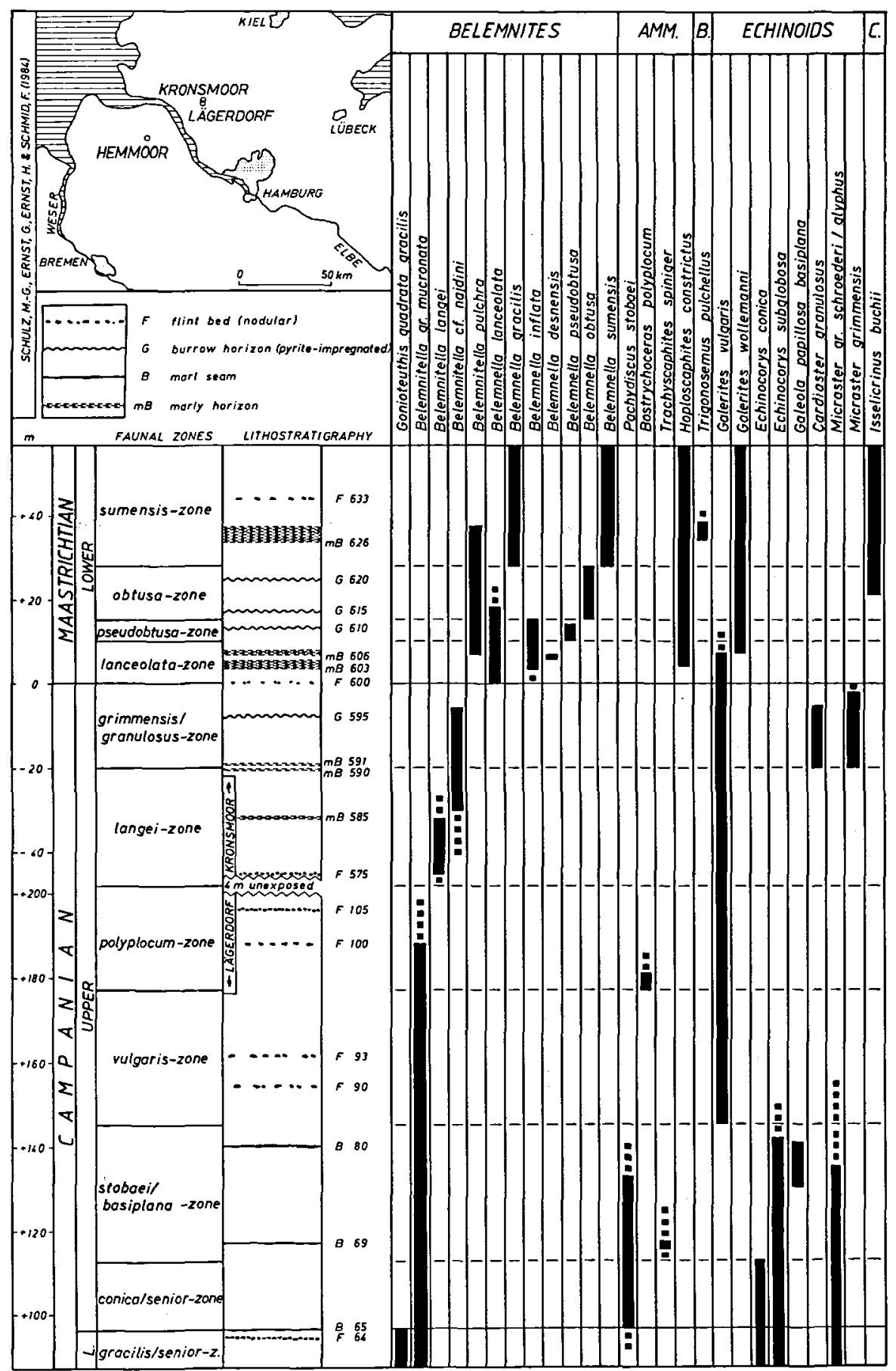

Fig. 2. Stratigraphic ranges of the most important guide fossils in the Upper Campanian and Lower Maastrichtian of Lägerdorf and Kronsmoor. 


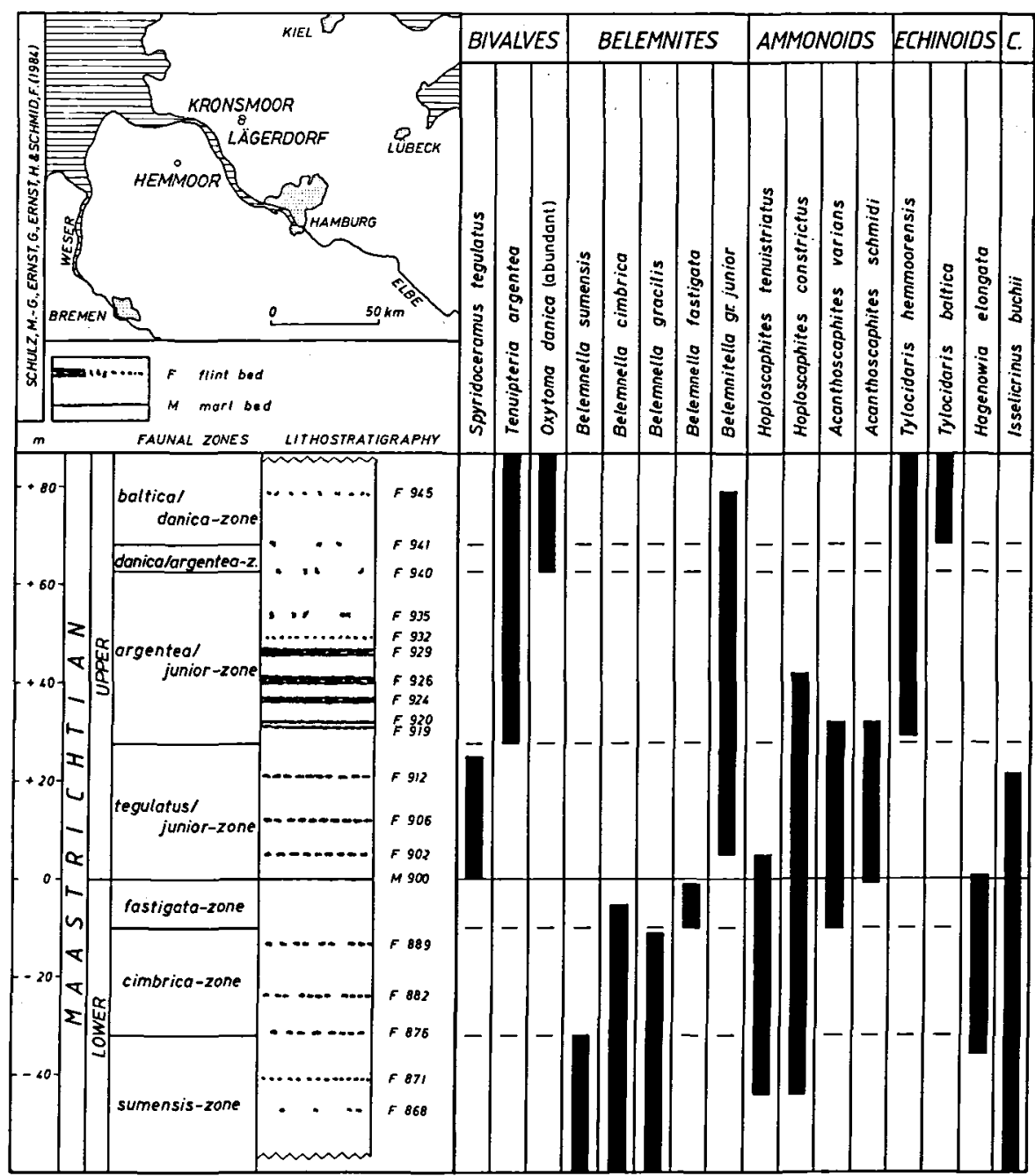

Fig. 3. Stratigraphic ranges of the most important guide fossils in the Lower and Upper Maastrichtian of Hemmoor. Corrections added in proof 1. Belemnella cimbrica is restricted to the cimbrica - and lower fastigata-zones. 2. Doubtful specimens of Spyridoceramus tegulatus have also been found in the Lower Maastrichtian at Hemmoor.

Hagenowia: G. Ernst \& Schulz 1971, Schmid 1972; asteroids: Schulz \& Weitschat 1971, 1975, 1981), mesofauna (e.g. micromorphic brachiopods: Surlyk 1982; Isocrania: H. Ernst in press; serpulids: Jäger 1983), and microfauna (e.g. benthonic foraminifers: Koch in Ernst \& Schulz 1974, Koch in Schmid 1975, Koch 1977; ostracods: Clarke 1982, 1983) have been studied in detail. Especially in the Coniacian and Santonian, there is excellent correspondence between the micro- and macro-palaeontologically defined boundaries. Studies of the planktonic foraminifers (W. Weiss, Hannover) and the calcitic nan- noplankton (P. Čepek, Hannover) are planned as contributions to Schulz et al. (in prep.).

\section{Stage boundaries (fig. 4)}

In the following, the stage boundaries from the Coniacian to the Maastrichtian of the Kronsmoor-Lägerdorf-Hemmoor section are described and compared with other sections and some proposals for boundary definitions and stratotypes are given. Owing to their long absolute time duration, the substage boundaries of the Lower and 


\begin{tabular}{|c|c|c|}
\hline \multirow{2}{*}{ 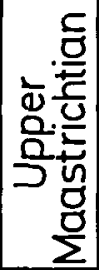 } & $\begin{array}{l}\text { 岛 } \\
\text { 응 }\end{array}$ & \begin{tabular}{l|l} 
not exposed & $\begin{array}{l}\text { * first I+ last occurrence } \\
\text { e (ee) earlier (much) /I(II) later (much) }\end{array}$ \\
$*$ Tylocidaris baltica (SCHLÜTER,1892) & than the boundary
\end{tabular} \\
\hline & 产 & $\begin{array}{l}\text { e * Meonia semiglobularis (POSSELT, } 1894 \text { ) } \\
\text { * Belemnitella junior NOWAK, } 1913\end{array}$ \\
\hline \multirow{3}{*}{ 立兽 } & 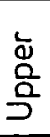 & $\begin{array}{l}\text { + Belemnella fastigata SCHULZ, } 1979 \\
\text { e+ Belemnella cimbrica BIRKELUND, } 1957 \\
\text { * Terebratulina subtilis STEINICH, } 1965 \\
\text { * Belemnella sumensis JELETZKY } 1949\end{array}$ \\
\hline & & +Belemnella obtusa SCHULZ, 1979 \\
\hline & 岇 & $\begin{array}{l}1 \text { * Hoploscaphites constrictus (SOWERBY, 1818) } \\
\text { * Belemnella lanceolata (SCHLOTHEIM, 1813) } \\
\end{array}$ \\
\hline \multirow{2}{*}{ 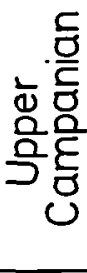 } & $\begin{array}{l}\frac{\grave{\nu}}{0} \\
\text { 음 }\end{array}$ & * Bostrychoceras polyplocum (F.A.ROEMER, 1841) \\
\hline & 产 & $\begin{array}{l}\text { ee* Belemnitella senior NOWAK, } 1913 \\
11 * \text { Trachyscaphites spiniger (SCHLÜTER, 1872) }\end{array}$ \\
\hline \multirow{2}{*}{ 엉 } & $\begin{array}{l}\text { 品 } \\
\text { 응 }\end{array}$ & $\begin{array}{l}\text { +Gonioteuthis quadrata gracilis (STOLLEY, 1892) } \\
\text { * Galeola senonensis (D'ORBIGNY, 1853) }\end{array}$ \\
\hline & 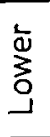 & $\begin{array}{l}\qquad 11+\text { Offaster pilula (LAMARCK, 1816) } \\
\text { * Gonioteuthis granulataquadrata (STOLLEY, 1897) }\end{array}$ \\
\hline \multirow{3}{*}{ 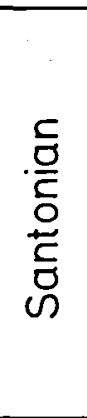 } & $\begin{array}{l}\text { 产 } \\
\text { 음 }\end{array}$ & $\begin{array}{l}\text { +Gonioteuthis granulata (BLAINVILLE, } 1827 \text { ) } \\
+ \text { + Marsupites testudinarius (SCHLOTHEIM, 1820) } \\
\text { e * Uintacrinus socialis GRINNELL, } 1876 \\
\text { * Gonioteuthis granulata (BLAINVILLE, } 1827 \text { ) }\end{array}$ \\
\hline & $\frac{0}{\frac{0}{D}}$ & $\begin{array}{l}\text { +Gonioteuthis westfalicagranulata (STOLLEY, 1897) } \\
\text { * Inoceramus cordiformis SOWERBY, } 1823\end{array}$ \\
\hline & 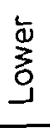 & $\begin{array}{l}\text { * Inoceramus pachti ARCHANGELSKY, } 1916 \\
\text { * Inoceramus undulatoplicatus F. ROEMER, } 1852\end{array}$ \\
\hline \multirow{4}{*}{ 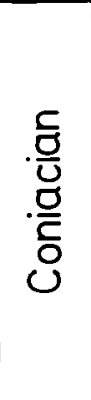 } & 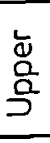 & $\begin{array}{c}\text { e+ Inoceramus involutus SOWERBY, } 1829 \\
\text { e * Inoceramus fasciculatus HEINE, } 1929 \\
\text { Guide fossil (Inoceramus subquadratus SCHLÜTER 1887) }\end{array}$ \\
\hline & $\frac{\mathscr{Q}}{\bar{g}}$ & * Inoceramus koeneni G.MÜLLER, 1887 \\
\hline & $\grave{\omega}$ & + Inoceramus deformis MEEK, 1876 \\
\hline & دَ & not exposed $\longdiv { M . - G . S C H U L Z , G . E R N S T , H . E R N S T ~ \& ~ F . S C H M I D ( 1 9 8 4 ) ~ }$ \\
\hline
\end{tabular}

Fig. 4. Biostratigraphic definition of stage and substage boundaries in the composite White Chalk section of LăgerdorfKronsmoor-Hemmoor. Additionally used key species are indented. 
Upper Campanian and the Lower and Upper Maastrichtian are also discussed.

Turonian/Coniacian boundary

This boundary was not reached by the completely cored exploration borehole in the Schinkel quarry. Only the uppermost part of the Inoceramus (Cremnoceramus) deformis (Meek) zone, which is relatively thick in northwest Germany, is present in the bottom six metres of the core (G. Ernst \& Schulz 1974, p. 12, Fig. 1). The $I$. deformis zone, which was previously assigned to the upper Turonian as defined by German stratigraphers, is now placed together with the underlying $I$. erectus zone in the Lower Coniacian in conformity with international convention.

\section{Coniacian/Santonian boundary}

This boundary in Lägerdorf was originally defined by the first occurrence of inoceramids of the pachti/cardissoides group (G. Ernst \& Schulz 1974 , p. 16), following the definition proposed for northwest and east Germany by Seitz (1961. p. 36; 1965. p. 133), Tröger \& Haller (1966. p. 88). According to Seitz (1961) the index fossil generally used for the Lower Santonian, Inoceramus (Cladoceramus) undulatoplicatus Roemer, first occurs at other northwest German sites a short distance above the appearance of $I$. (Sphenoceramus) gr. pachti/cardissoides. Seitz called this interval the Sphenoceramus (1961) and cardissoides (1965) "Teilzone". But in Lägerdorf, small fragments of undulatoplicatus-like inoceramids have been found at the same level as the first specimens of the $I$. pachti/cardissoides group.

Because this species has the following advantages, we now propose to define the stage boundary with the appearance of $I$. undulatoplicatus:

1. wide distribution in western and eastern Europe and North America,

2. abundant occurrence in a distinct level immediately above the boundary in several areas, (e.g. England and northern Spain),

3. possibility of determination even in fragments and bore cores on the basis of the characteristic divergent ribs.

Additionally, the Coniacian/Santonian junction is characterized by the extinction of several inoceramid species near the boundary, in particular, I. involutus Sowerby, I. fasciculatus Heine, and $I$. subquadratus Schlüter (Seitz 1965, Tröger \& Haller 1966).

Inoceramus subquadratus, which was used by Seitz for defining the Upper Coniacian in Westphalia, has not been found in Lägerdorf or Lüneburg, probably owing to the different facies (see discussion in G. Ernst \& Schulz 1974, p. 13).

According to Koch (in G. Ernst \& Schulz 1974. p. 15), the first appearance of Stensioeina granulata polonica Witwicka (= St. praeexsculpta "form F") in Lägerdorf occurs exactly at the base of the Santonian as defined by inoceramids. Bailey et al. (1983b, p. 11), however, found this subspecies in samples from the Upper Coniacian (bucailli/praewestfalica zone) of Lägerdorf.

Species of the genus Texanites (I. texanum auct.) have been used for defining the base of the Santonian, especially in France. They occur rarely in Westphalia, but are not found in Lägerdorf, where ammonites are completely absent in this part of the section.

Lägerdorf should not be used as stratotype for the Coniacian/Santonian boundary because this part of the section has recently been flooded and there are several indications for reduced sedimentation around the boundary (G. Ernst \& Schulz 1974. p. 16). Suitable stratotypes for this boundary are the coastal section in Kent (southern England) and the cement quarry Olazagutia near Alsasua in Navarra (northern Spain). Both sections have been studied in detail during the last several years (Bailey et al. 1983a; G. Ernst, Lamolda et al., unpublished). Inoceramus undulatoplicatus occurs in these sections together with other inoceramid species and a rich echinoid fauna.

\section{Santonian/Campanian boundary}

In northwest Germany, this boundary was formerly set at either the base or the top of the range zone of Gonioteuthis granulataquadrata (Stolley) (= Upper "Granulaten-Senon" sensu Stolley 1897 , p. 281 ; 1930 , p. 189). Both possibilities have been discussed in detail by Jeletzky (1958) and Schmid (1959). In the following years, the base of the granulataquadrata zone was accepted as the stage boundary by most authors since this level seems to coincide with the Santonian/Campanian boundary in France as defined by ammonites.

Detailed analysis of the Gonioteuthis lineage in 
Lägerdorf showed that the level of phylogenetic development of $G$. granulataquadrata from $G$. granulata in this section is exactly coincident with the extinction level of the free-living crinoid Marsupites testudinarius Schlotheim (G. Ernst 1963a, p. $107 ; 1966$, p. $138 ; 1968$, p. 275 ). M. testudinarius, which had a nearly global distribution (Europe, Asia, Australia, Africa, North America), can be easily identified, even in fragments, and is normally very common, at least in Europe. The extinction of this species is very convenient for practical determination of the Santonian/ Campanian boundary in the field. This definition has been used by several authors (e.g. Diener 1966, p. 15) for East Germany and Naidin (1983) for Russia. Bailey et al. (1983a,b) have set the boundary in southern England somewhat higher: at the top of the range of Uintacrinus anglicus Rasmussen.

Seitz (1965, p. 124) considered it possible that $M$. testudinarius found at some sites in Westphalia were within the lowermost Campanian (granulataquadrata zone), but G. Ernst (1968, p. 275) demonstrated that the extinction of $M$. testudinarius is coincident with the transition level from G. granulata to G. granulataquadrata in all of the sections he had investigated.

$M$. testudinarius is apparently very useful for determination of the Santonian/Campanian boundary. However, there is general agreement now that stage boundaries should not be defined by the extinction of a guide species.

Therefore, we propose to define the Santonian/ Campanian boundary with the appearance (= phylogenetic development) of Gonioteuthis granulataquadrata (Stolley). Since the phylogenetic development in the Gonioteuthis lineage was rather rapid at the Santonian/Campanian junction, relatively small populations (ca. 10 specimens) are sufficient to reliably determine the boundary ( $G$, Ernst 1964). In Lägerdorf this boundary is about $1 \mathrm{~m}$ above the base of the "Grobkreide" complex (see above).

Owing to this facies change and since the boundary is rather poorly exposed, Lägerdorf is not suitable as a boundary stratotype. The coastal section in Sussex (southern England) would be suitable if enough Gonioteuthis material can be collected there.

Scaphites hippocrepis (Dekay), which has been used for defining the base of the Campanian (e.g.
Wiedmann 1979 , p. 343 , table 5), has not been found at Lägerdorf. In the Misburg area, it first occurs in the upper part of the Lower Campanian (Galeola papillosa zone), but it is known from the lower part of the Lower Campanian in Westphalia (Schmid \& G. Ernst 1975, p. 325, fig. 2).

Inoceramids might also be useful for defining the boundary, but the exact ranges and the systematics are not sufficiently well known. Inoceramids of the lingualpatootensis group first appear in our section in the middle part of the $M$. testudinarius zone (Seitz 1965, p. 134; Heinz 1928). It is possible that the level of appearance of $I$. (Endocostea) balticus Böhm is nearly coincident with the boundary proposed above.

The appearance of Bolivinoides strigillatus (Chapman), which has a very wide distribution, is a very distinct micropalaeontological boundary. In Lägerdorf, $B$. strigillatus first appears at the base of the $M$. testudinarius zone (Koch in G. Ernst \& Schulz 1974, p. 22, fig. 3). In the Hannover area, the appearance of this species is definitely much earlier: near the base of the $U$. socialis zone (Koch 1977, p. 18). In England, B. strigillatus first appears in the upper part of the $U$. socialis zone (Bailey et al. 1983a).

\section{Lower/Upper Campanian boundary}

This boundary in northwest Germany was formerly defined either with the first occurrence of Belemnitella senior Nowak or with the extinction of the genus Gonioteuthis (G. quadrata gracilis (Stolley)). Both species occur together in a 10-20 $\mathrm{m}$ thick horizon ("overlap-Bereich" = gracilis/ senior Zone, Schmid 1959).

According to Jeletzky (1958, p. 46), the boundary in west and northwest Europe is best defined with the extinction of the genus Gonioteuthis. Although there is general agreement that boundaries, in principle, should not be defined by the extinction of guide species, this proposal has since been accepted by most authors since this definition has been very convenient.

In Lägerdorf, the boundary has been set in a thin marl bed (B65) $0.15 \mathrm{~m}$ above the level at which the last representative of the genus Gonioteuthis has been found. The first rare specimens of Belemnitella senior in Lägerdorf occur about $12 \mathrm{~m}$ below this level (Schulz 1978, p. 79).

The first occurrence of ammonites in the Lägerdorf section is in the Lower Campanian. 
But it is difficult to use ammonites for defining the base or top of the gracilis/senior zone. Only Pachydiscus stobaei Moberg may be suitable. In Lägerdorf, the first specimen of $P$. stobaei was found $1 \mathrm{~m}$ above the top of this zone (B65). In Misburg, however, small specimens of $P$. stobaei occur already in the upper part of the gracilis/ senior zone (Khosrovschahian 1972, p. 41).

Trachyscaphites spiniger (Schlüter), used for defining this boundary in other areas, e.g. Poland (Błaszkiewicz 1980, p. 13) and Spain (Wiedmann 1979, table 5), first occurs in northwest Germany one zone higher in the lower part of the stobaeil basiplana zone and is quite common in the middle part of this zone in Misburg (Schmid \& G. Ernst 1975, p. 338). In Lägerdorf, only one specimen has been found in the lower part of the stobaeilbasiplana zone (Schulz 1978, p. 80).

The boundary as defined above (extinction of Gonioteuthis) can be recognized micropalaeontologically by the appearance of Bolivinoides laevigatus Marie and Neoflabellina numismalis Wedekind (Koch 1977).

The cement quarries of Misburg and Höver near Hannover provide a much better reference section for the Lower/Upper Campanian boundary than Lägerdorf. Belemnites, ammonites, and echinoids are much more common, the section is extremely well exposed and it has been investigated in detail (G. Ernst 1963b, 1968; Khosrovschahian 1972; Abu-Maaruf 1975; Schmid \& G. Ernst 1975).

\section{Campanian/Maastrichtian boundary}

The base of the Maastrichtian is defined at Kronsmoor by the appearance of Belemnella lanceolata (Schlotheim), which at the same time is the first occurrence of the genus Belemnella (Schulz 1978, 1979). This definition was first proposed by Jeletzky (1951) for the boreal Upper Cretaceous and has since been generally accepted in northwest Europe.

Hoploscaphites constrictus (Sowerby) has long been regarded as the most important index fossil of the Maastrichtian. It is, however, not useful for defining the boundary in any known section because it is very rare in the Lower Maastrichtian (Birkelund 1982, p. 21; Schulz 1978, p. 28). Most of the known occurrences of $H$. constrictus belong to the Upper Maastrichtian, sometimes extending into the upper part of the Lower
Maastrichtian, (e.g. in Limburg, Cotentin, Bavaria, and in Denmark).

The first occurrence of $H$. constrictus at Kronsmoor was found 3.5 to $5 \mathrm{~m}$ above the first occurrence of $B$. lanceolata, indicating that there is no significant difference between the levels of appearance of the two species. This is the earliest record of $H$. constrictus in northwestern and central Europe. But also at Kronsmoor, it is extremely rare in the lower part of the Lower Maastrichtian. It does not become more common until the upper part of the Lower Maastrichtian (Belemnella sumensis zone) at Kronsmoor and Hemmoor (Birkelund 1982, fig. 1; Schulz 1978, p. 85).

Therefore, the first occurrence of Belemnella lanceolata is proposed for the definition of the Campanian/Maastrichtian boundary and Kronsmoor is proposed as boundary stratotype, as suggested earlier by Surlyk (1975, 1982, p. 260) and Schulz (1978, p. 84). This quarry will stay open and even be enlarged in the next several decades. Since there are no sedimentological signs of a hiatus at this level, the most complete and palaeontologically best documented section of the Campanian/Maastrichtian boundary known in northwest Europe is apparently the one at Kronsmoor.

Pachydiscus neubergicus (Hauer), which has also been considered for defining the lower boundary of the Maastrichtian, is known in northwest Germany only in the upper part of the Lower Lower Maastrichtian (Belemnella obtusa zone) of Lüneburg (Schlüter 1871-76, Schmid 1955, Schulz 1979). Blaskiewicz (1980) regarded this form as a separate subspecies ( $P$. neubergicus rarecostatus). $P$. neubergicus neubergicus in Poland is restricted to the upper part of the Lower Maastrichtian.

Bostrychoceras polyplocum (F. A. Roemer) has often been used as guide fossil for the uppermost Campanian. But in northwest Germany this species is restricted to the lowermost part of the Upper Upper Campanian: at Lägerdorf ca. $70 \mathrm{~m}$ and at Lüneburg ca. $40 \mathrm{~m}$ below the Campanian/ Maastrichtian boundary (Schulz 1978, fig. 3).

Lower/Upper Maastrichtian boundary This boundary is generally defined with the appearance of Belemnitella junior Nowak 1913 (Jeletzky 1951). 
In Hemmoor, the earliest $B$. ex gr. junior was found $4.9 \mathrm{~m}$ above the conspicuous marl layer M900 (Schulz \& Schmid 1983b, p. 25). This layer, which probably indicates a short interruption of chalk sedimentation (H. Ernst 1982), is a very characteristic lithostratigraphic marker horizon. Similar marl layers occur at the same level in Denmark (e.g. Hillerslev and Rørdal) and on Rügen. The stratigraphic position in these localities is additionally established by the appearance of the brachiopod Meonia semiglobularis (Posselt) immediately below the marl layer (Surlyk 1970).

The inoceramid Tenuipteria argentea (Conrad), which has a very wide distribution in the northern hemisphere, is apparently a useful index fossil for the Upper Maastrichtian (Dhondt 1983). Its appearance in Hemmoor is definitely much later than that of Belemnitella junior. This corresponds quite well with the findings in Limburg, where $T$. argenta is known only in the Maastricht Formation (Dhondt 1983, fig. 2), which spans only the upper part of the Upper Maastrichtian (Schulz \& Schmid 1983b, fig. 3).

\section{Dansk sammendrag}

Fire store kridtgrave i Nordtyskland viser et kombineret profil i skrivekridtfacies gående fra mellem coniacien til øvre maastrichtien. Mægtigheden af dette profil er $570 \mathrm{~m}$, og det er blevet inddelt biostratigrafisk i 33 zoner på basis af echinodermer, belemniter, muslinger og ammonitter.

Folgende forslag fremsættes for definition af etage grænser: (1) campanien-maastrichtien grænsen defineres ved første forekomst af Belemnella lanceolata; denne grænse er næsten identisk med første forekomst af Hoploscaphites constrictus. (2) santonien-campanien gransen defineres ved det phylogenetiske skifte fra Gonioteuthis granulata til $G$. granulataquadrata; denne granse er identisk med sidste forekomst af Marsupites testudinarius. (3) coniacien-santonien gransen defineres ved første forekomst af Inoceramus (Cladoceramus) undulatoplicatus; denne grænse er næsten identisk med første forekomst af $I$. pachti/cardissoides gruppen.

\section{References}

Abu-Maaruf, M. 1975: Feingliederung und Korrelation der Mergelkalk-Fazies des Unter-Campan von Misburg, Höver und Woltorf im ostniedersächsischen Becken. Ber. naturhist. Ges. Hannover 119, 127-204.

Bailey, H. W., Gale, A. S., Mortimore, R. N., Swiecicki, A. \& Wood, C. J. 1983a: The Coniacian - Maastrichtian Stages of the United Kingdom, with particular reference to southern England. Newsl. Stratigr. 12, 29-42.

Bailey, H. W., Gale, A. S., Mortimore, R. N., Swiecicki, A. \&
Wood, C. J. 1983b: Criteria for defining the Coniacian to Maastrichtian Stage Boundaries in England. Abstracts. Symposium on Cretaceous Stage Boundaries, 9-12, Copenhagen.

Birkelund, T. 1982: Maastrichtian Ammonites from Hemmoor, Niederelbe (NW-Germany). Geol. Jb. A 61, 13-33.

Blaskiewicz, A. 1980: Campanian and Maastrichtian of the Middle Vistula River valley, Poland: A stratigraphic-paleontological study. Pol. Inst. Geol. Pr. 92, 63 pp.

Bromley, R. G. 1979: Chalk and bryozoan limestone: facies, sediments and depositional environments. In: T. Birkelund \& R. G. Bromley: Cretaceous-Tertiary boundary events. I. The Maastrichtian and Danian of Denmark 16-32, Copenhagen.

Clarke, B. 1982: Die Gattung Cytherelloidea ALEXANDER, 1929 (Ostacoda) im Schreibkreide-Richtprofil von Lägerdorf-Kronsmoor-Hemmoor (NW-Deutschland). Geol. Jb. A 61, 35-71.

Clarke, B. 1983: Die Cytheracea (Ostracoda) im Schreibkreide-Richtprofil von Lägerdorf-KronsmoorHemmoor (Coniac bis Maastricht; Norddeutschland). Mitt. Geol.-Paläont. Inst. Univ. Hamburg, 54, 65-168.

Dhondt, A. V. 1983: Tegulated Inoceramids and Maastrichtian Biostratigraphy. Newsl. Stratigr. 12, 43-53.

Diener, J. 1967: Die Paläogeographie der Kreide im Nordteil der DDR in Beziehung zu den Nachbargebieten. Ber. deutsch. Ges. geol. Wiss., A, Geol. Paläontol. 12, 289-313.

Ernst, G. 1963a: Stratigraphische und gesteinschemische Untersuchungen im Santon und Campan von Lägerdorf (SWHolstein). Mitt. Geol. Staatsinst. Hamburg, 32, 71-127.

Ernst, G. 1963b: Zur Feinstratigraphie und Biostratonomie des Obersanton und Campan von Misburg und Höver bei Hannover. Mitt. Geol. Staatsinst. Hamburg, 32, 128-147.

Ernst, G. 1964: Ontogenie, Phylogenie und Stratigraphie der Belemnitengattung Gonioteuthis BAYLE aus dem nordwestdeutschen Santon/Campan, Fortschr. Geol. Rheinld. u. Westf. 7, 113-174.

Ernst, G. 1966: Fauna, Ökologie und Stratigraphie der mittelsantonen Schreibkreide von Lägerdorf (SW-Holstein). Mitt. Geol. Staatsinst. Hamburg 35, 115-150.

Ernst, G. 1968: Die Oberkreide-Aufschlüsse im Raume Braunschweig - Hannover und ihre stratigraphische Gliederung mit Echinodermen und Belemniten. 1. Teil: Die Jüngere Oberkreide (Santon-Maastricht). Beih. Ber. Naturhist. Ges. Hannover 5, 235-284.

Ernst, G. 1971: Biostratigraphische Untersuchungen über die Ontogenie und Phylogenie der Offaster/Galeola - Stammesreihe aus der borealen Oberkreide. N. Jb. Geol. Paläont., Abh. 139, 169-225.

Ernst, G. \& Schulz, M.-G. 1971: Die Entwicklungsgeschichte der hochspezialisierten Echiniden-Reihe Infulaster Hagenowia in der borealen Oberkreide. Paläont. Z. 45, 120-143.

Ernst, G. \& Schulz, M.-G. 1974: Stratigraphie und Fauna des Coniac und Santon im Schreibkreide-Richtprofil von Lägerdorf (Holstein). Mitt. Geol.-Paläont. Inst. Univ. Hamburg, 43, 5-60.

Ernst, H. 1978: Zu Bathymetrie und Sedimentstrukturen der Schreibkreide von Lägerdorf/Holstein (Coniac-Santon): Eine quatitative Analyse der Foraminiferen-Faunen. Mitt. Geol.-Paläont. Inst. Univ. Hamburg, 48, 53-78.

Ernst, H. 1982: The Marl Layer M 100 in the Maastrichtian of Hemmoor - An Example of Selective $\mathrm{CaCO}_{3}$ Dissolution. Geol. Jb. A 61, 109-127.

Ernst, H. in press: Ontogenie, Phylogenie und Autökologie des inarticulaten Brachiopoden Isocrania in der SchreibkreideFazies NW-Deutschlands (Coniac - Maastricht). Geol. Jb.

Heinz, R. 1928: Das Inoceramen-Profil der Oberen Kreide Lüneburgs (Beiträge zur Kenntnis der obercretazischen Inoceramen I). Jber. niedersächs. geol. Ver. 21, 64-81. 
Jäger, M. 1983: Serpulidae (Polychaeta sedentaria) aus der norddeutschen höheren Oberkreide. - Systematik, Stratigraphie, Ökologie. Geol. Jb. A 68, 219 pp.

Jeletzky, J. A. 1951: Die Stratigraphie und Belemnitenfauna des Obercampan und Maastricht Westfalens, Nordwestdeutschlands und Dänemarks sowie einige allgemeine Gliederungs-Probleme der jüngeren borealen Oberkreide Eurasiens. Beih. Geol. Jb. 1, 142 pp.

Jeletzky, J. A. 1958: Die jüngere Oberkreide (Oberconiac bis Maastricht) Südwestrußlands und ihr Vergleich mit der Nordwest- und Westeuropas. Beih. Geol. Jb. 33, 157 pp.

Khosrovschahian, R. 1972: Feinstratigraphie und faziesanalytische Untersuchungen im Campan von Misburg bei Hannover. Dissertation Braunschweig, $84 \mathrm{pp}$.

Koch, W. 1977: Stratigraphie der Oberkreide in Nordwestdeutschland (Pompeckjsche Scholle). Teil 2: Biostratigraphie in der Oberkreide und Taxonomie von Foraminiferen. Geol. Jb. A 38, 11-123.

Naidin, D. P. 1983: The Upper Cretaceous Stage Boundaries of the east part of the European paleobiogeographic region. Abstracts Symposium on Cretaceous Stage Boundaries, 136-139, Copenhagen.

Schlüter, C. 1871-76: Die Cephalopoden der oberen deutschen Kreide. 1. Palaeontographica 21, $261 \mathrm{pp}$.

Schmid, F. 1955: Biostratigraphie der Grenzschichten Maastricht-Campan in Lüneburg und in der Bohrung Brunhilde. 1. Teil: Megafauna und Schichtfolge. Geol. $J b$. 70, 339-356.

Schmid, F. 1959: La Définition des limites Santonien - Campanien et de Campanien inférieur-supérieur en France et dans le Nord-Ouest de l'Allemagne. Congr. Soc. savantes 84, 535-546, Paris.

Schmid, F. 1972: Hagenowia elongata (NIELSEN), ein hochspezialisierter Echinide aus dem höheren UnterMaastricht NW-Deutschlands. Geol. Jb. A 4, 177-195.

Schmid, F. 1975: Lithostratigraphie und Biostratigraphie der feuersteinführenden Schreibkreide des Unter- und Obermaastricht von Hemmoor (Niederelbe). Exk. A, 45. Jahr. Vers. Paläont. Ges., 21 pp.

Schmid, F. 1982: Das erweiterte Unter-/Ober-MaastrichtGrenzprofil von Hemmoor, Niederelbe (NW-Deutschland). Geol. $J b$. A 61, 7-12.

Schmid, F. \& Ernst G. 1975: Ammoniten aus dem Campan der Lehrter Westmulde und ihre stratigraphische Bedeutung. 1. Teil: Scaphites, Bostrychoceras, Hoplitoplacenticeras. Ber. naturhist. Ges. Hannover, 119, 315-359.

Schmid, F. \& Schulz, M.-G. 1979: Belemnella gracilis (Archangelsky) von Adelholzen bei Siegsdorf in Oberbayern. Aspekte der Kreide Europas. IUGS Series A, Nr. 6, 151158.

Scholz, R. W. 1973: Zur Sedimentologie und Kompaktion der Schreibkreide von Lägerdorf in SW Holstein. $N$. $J b$. Miner. Abh. 118, 111-133.

Schulz, M.-G. 1978: Zur Litho- und Biostratigraphie des Obercampan - Untermaastricht von Lägerdorf und Kronsmoor (SW-Holstein). Newsl. Stratigr. 7, 73-89.

Schulz, M.-G. 1979: Morphometrisch-variationsstatistische Untersuchungen zur Phylogenie der Belemnitengattung Belemnella im Untermaastricht NW-Europas. Geol. Jb. A $47,157 \mathrm{pp}$.

Schulz, M.-G. \& Schmid, F. 1983a: Die Belemniten der Inoceramen-Mergel (Buntmergelserie, Ultrahelveticum, Unter-Maastricht) des Moosgrabens SE Siegsdorf (Oberbayern) und ihre stratigraphische Bedeutung. Zitteliana $10,653-661$.
Schulz, M.-G. \& Schmid, F. 1983b: Das Ober-Maastricht von Hemmoor (N-Deutschland): Faunenzonen-Gliederung und Korrelation mit dem Ober-Maastricht von Dänemark und Limburg. Newsl. Stratigr. 13, 21-39.

Schulz, M.-G. \& Weitschat, W. 1971: Asteroideen aus der Schreibkreide von Lägerdorf (Holstein) und Hemmoor (Nord-Niedersachsen). Mitt. Geol. Paläont. Inst. Univ. Hamburg, 40, 107-130.

Schulz, M.-G. \& Weitschat, W. 1975: Phylogenie und Stratigraphie der Asteroideen der nordwestdeutschen Schreibkreide. Teil I: Metopaster/Recurvaster- und Calliderma/Chomataster-Gruppe. Mitt. Geol. Paläontol. Inst. Univ. Hamburg, 44, 249-284.

Schulz, M.-G. \& Weitschat, W. 1981: Phylogenie und Stratigraphie der Asteroideen der nordwestdeutschen Schreibkreide. Teil II: Crateraster/Teichaster-Gruppe und Gattung Ophryaster. Mitt. Geol. Paläontol. Inst. Univ. Hamburg, $51,27-42$.

Seitz, O. 1961: Die Inoceramen des Santon von Nordwestdeutschland. 1. Teil: Die Untergattungen Platyceramus, Cladoceramus und Cordiceramus. Beih. geol. Jb. 46, 186 pp.

Seitz, O. 1965: Die Inoceramen des Santon und Unter-Campan von Norddeutschland. II. Teil: Biometrie, Dimorphismus und Stratigraphie der Untergattung Sphenoceramus J. Böhm. Beih. Geol. Jb. 69, 194 pp.

Stolley, E. 1897: Ueber die Gliederung des norddeutschen und baltischen Senon sowie die dasselbe charakterisierenden Belemniten. Arch. Anthropol. Geol. Schlesw.-Holst. 2, 215-300.

Stolley, E. 1930: Einige Bemerkungen über die Kreide Südskandinaviens. Medd. Lunds Geol.-Mineral. Inst. 44, 157190.

Surlyk, F. 1970: Die Stratigraphie des Maastricht von Dänemark und Norddeutschland aufgrund von Brachiopoden. Newsl. Stratigr. 1, 7-16.

Surlyk, F. 1975: Die Brachiopoden der Hemmoorer Schreibkreide. Paläont. Ges. 45. Jahresvers. Kurzfassung der Vorträge, 1 p., Hannover.

Surlyk, F. 1982: Brachiopods from the Campanian-Maastrichtian boundary sequence, Kronsmoor (NW Germany). Geol. Jb. A 61, 259-277.

Tröger, K.-A. \& Haller, W. 1966: Biostratigraphie der Inoceramen und einiger ausgewählter Ammoniten, Belemniten und Echinodermaten des Unter-Coniac bis Unter-Campan in der DDR. Abh. zentr. geol. Inst., H. 55, 84-91.

Valeton, I. 1959: Eine vulkanische Tufflage aus der Oberkreide von Hemmoor/Niederelbe. N. Jb. Geol. Paläont., Mh. 5, 193-204.

Valeton, I. 1960: Vulkanische Tuffiteinlagerungen in der nordwestdeutschen Oberkreide. Mitt. Geol. Staatsinst. Hamburg, 29, 26-41.

Voigt, E. 1954: Nachweis des Uintacrinus-.Horizontes in der Kreide Schleswig-Holsteins. Neues Jb. Geol. Paläont., Mh. 5, 224-228.

Wetzel, W. 1942: Über die oberste Kreide von Barsbeck bei Hemmoor. Z. deutsch. geol. Ges. 94, 41-43.

Wiedmann, J. 1979: Die Ammoniten der NW-deutschen, Regensburger und Ostalpinen Oberkreide im Vergleich mit den Oberkreidefaunen des westlichen Mediterrangebiets, Aspekte der Kreide Europas. IUGS Series A, No. 6, 335350 . 